\title{
Impact and Awareness of Soil Health Card on Soybean Production Technology in Ujjain block of Ujjain District, M.P, India
}

\author{
Ms. Poonam Chakrawarty ${ }^{1}$, Dr. Sandhya Choudhary ${ }^{2}$, Dr. Abhay Wankhede ${ }^{3}$, \\ Dr. S.K. Jain ${ }^{4}$
}

\author{
${ }^{1}$ M.Sc. Extension Education Final Year Student 2018 \\ ${ }^{2}$ Associate Professor \& Head, Extension Education, College of Agriculture, Indore \\ ${ }^{3}$ Assistant Professor, Extension Education, College of Agriculture, Indore \\ ${ }^{4}$ Professor \& Head Agricultural Economics, College of Agriculture, Indore
}

\begin{abstract}
The SHC is a simple document, which contains useful data on soil based on chemical analysis of the soil to describe soil health in terms of its nutrient availability and its physical and chemical properties. The SHC is a simple document, which contains useful data on soil based on chemical analysis of the soil to describe soil health in terms of its nutrient availability and its physical and chemical properties. An amount of Rs 568 crore (US\$89 million) was allocated by the government for the scheme. In 2016 Union budget of India,100 crore (US\$16 million) had been allocated to states for making soil health cards and set up labs. The target for 2015-16 was to collect 100 lakh soil samples and test these for issue of soil health cards. The government plans to distribute 14 crore soil health cards by 2017. it is therefore, important to find out the impact and awareness associated with farmer towards the usefulness and application of Soil Health Card on their agricultural production, diversification and cropping pattern. Considering the above points, an effort will be made to conduct study with the following objective with 120 beneficiaries of KVK Ujjain, M.P. The main findings is majority of beneficiaries were found to have high level of awareness about various components of soybean production technology followed by medium and low level of awareness about various components of Soybean production technology.
\end{abstract}

Introduction

Soil is one of the elements required for farming as it provides nutrients to the plants. Healthy soil containing all the elements for growth and development of crop and on the other hand soil deprived of one or more elements either reduces production or degrades quality of crops. Proportion and quantity of macro and micro nutrients refers to the soil health. As far as agriculture production is concerned, soil health plays a vital role in ensuring sustainable production with optimizing the utilization of fertilizers and reducing its wastage. Soil Health Card (SHC) is a scheme launched by the Government of India in February 2015 in Gujarat. The SHC is a simple document, which contains useful data on soil based on chemical analysis of the soil to describe soil health in terms of its nutrient availability and its physical and chemical properties. status of farmers.

Madhya Pradesh is known as the Soybean bowl of India, because major chunk of Soybean production is contributed by Madhya Pradesh State alone. Nutrients are essential for plants' growth and development. When soil nutrients are missing or in short supply, plants suffer from nutrient deficiency and stop growing. Then, application of fertilizers to soils as per requirement is very important to provide balanced nutrients to the plants grown on it. Considering the growing importance of soil testing.

Keywords - Soil Health Card, Soybean Production, Soybean bowl of India.

\section{OBJECTIVE}

To know the awareness of SHC holders regarding its utility.

\section{REVIEW LITERATURE}

Patel and Chauhan (2012) in their study revealed that more than one third $(35.00 \%)$ of farmers had neutral attitude towards soil health card programme, while 20.00 per cent of farmers had strongly favourable attitude. Equal number $(17.00 \%)$ of farmers had unfavourable and strongly unfavourable attitude towards soil health card programme. Rest of them $(11.00 \%)$ had favourable attitude towards soil health card programme.

Hossen et al (2013) reported that most of the respondents $(77.00 \%)$ had positively observed the climate change occurred and only 23.00 per cent did not realize 
about climate change. They further 26 found that most of the farmers $(57.2 \%)$ had no idea about soil carbon but they followed various soil management practices (crop rotation $90.3 \%$, irrigation $98.96 \%$ and fertilization $96.8 \%$ ) for better crop production which helps to increase soil organic carbon in the farmer's field.

Abebe and Abera (2014) indicated that there was a significant difference between farmers and Agricultural and Rural Development workers regarding their perception towards gender and gender mainstreaming, moderately female farmers have higher degree of perception than male farmers in rural areas. Relatively female workers have higher degree of perception than male workers in Agricultural and Rural Development workers.

\section{METHODOLOGY}

For fulfilment of these objectives, the mult is tage sampling technique has been adopted for selection of sample for present study. Ujjain district comprises of six development blocks. All the six development blocks of the district comes under the SHC for Soybean production out of which one block i.e. Ujjain was selected due to higher number of SHC holders in the block .Ujjain block constitutes of twenty five villages out of which four villages, were selected by the SHC Center for improved cultivation practices of Soybean production, namely Undasa, Madhaopura, Narvar and Chandesara villages. List of 300 SHC holders (2015-16) of the selected four villages was obtained from KVK, Ujjain and 120 farmers have been selected randomly for present study.

\section{RESULT \& DISCUSSION}

Level of Awareness of Soil Health Card beneficiaries regarding Soybean production technology:

Awareness is defined as knowledge about something exists, or understanding of a situation or subject at the present time based on information or experience. It is a quality or state of being aware. For the present investigation, the awareness level of selected beneficiaries of SHC regarding Soybean production technology was assessed and was presented in the table below:

Table: Distribution of beneficiaries according to their extent of awareness in respect of SHC regarding Soybean production technology. $(n=120)$

\begin{tabular}{|l|l|c|c|c|}
\hline S.No & \multicolumn{1}{|c|}{ Components } & \multicolumn{3}{|c|}{ Extent of Awareness } \\
\cline { 3 - 5 } & & Least & Partial & Full \\
\hline 1. & Ploughing and land preparation & 22 & 40 & 58 \\
& & $(18.33)$ & $(33.34)$ & $(48.33)$ \\
\hline 2. & $\begin{array}{l}\text { Improved varieties of Soybean } \\
\text { (JS-9305 and JS-335) }\end{array}$ & 18 & 45 & 57 \\
& $(15.00)$ & $(37.50)$ & $(47.50)$ \\
\hline 3. & Seed treatment (Carbendazim+captan@ 3 gm/kg & 20 & 48 & 52 \\
& seed) & $(16.67)$ & $(40.00)$ & $(43.33)$ \\
\hline 4. & Soil type & 22 & 41 & 57 \\
& & $(18.33)$ & $(34.16)$ & $(47.50)$ \\
\hline 5. & Method of sowing(By Seed-Drill \& acc. to the & 15 & 46 & 59 \\
& availability ofmachinery) & $(12.50)$ & $(38.33)$ & $(49.16)$ \\
\hline 6. & Cropping pattern & 30 & 32 & 58 \\
& & $(25.00)$ & $(26.66)$ & $(48.33)$ \\
\hline 7. & Cropping diversification & 28 & 52 & 40 \\
& & $(23.33)$ & $(43.33)$ & $(33.34)$ \\
\hline 8. & Type of fertilizer & 30 & 45 & 45 \\
& & $(25.01)$ & $(37.49)$ & $(37.50)$ \\
\hline 9. & Fertilizer dose application & 35 & 43 & 42 \\
& & $(29.16)$ & $(35.83)$ & $(35.00)$ \\
\hline 10. & Integrated weed management & 28 & 36 & 56 \\
& & $(23.33)$ & $(30.00)$ & $(46.67)$ \\
\hline 11. & Integrated pest management & 32 & 42 & 46 \\
& & $(26.66)$ & $(35.00)$ & $(38.33)$ \\
\hline 12. & Level of production & 30 & 40 & 50 \\
& & $(25.00)$ & $(33.34)$ & $(41.66)$ \\
\hline
\end{tabular}

(Figure in parentheses shows percentage) 
The above table describes the distribution of SHC beneficiaries as per their obtained mean score of knowledge in the sub component of the programme.

i. Awareness regarding ploughing and land
preparation:

Regarding awareness of field preparation showed, out of the total beneficiaries, majority of the beneficiaries $(48.33 \%)$ pertained high level of awareness followed by partial awareness (33.34\%) and least awareness $(18.33 \%)$.

\section{ii. Awareness regarding improved varieties of Soybean:}

Regarding awareness of improved varieties of Soybean JS-9305 and JS-355 showed, out of the total beneficiaries, majority of the beneficiaries $(47.50 \%)$ pertained high level of awareness followed by partial awareness $(37.50 \%)$ and least awareness $(18.33 \%)$.

\section{iii. Awareness regarding seed treatment:}

Regarding awareness of seed treatment (Carbendazim+captan@3 g m/kg seed) showed, out of the total beneficiaries, majority of the beneficiaries i.e. $(43.33 \%)$ pertained high level of awareness followed by partial awareness $(40.00 \%)$ and least awareness (16.67\%).

\section{iv. Awareness regarding soil type:}

Regarding awareness of soil type showed, out of the total beneficiaries, majority of the beneficiaries (47.50\%) pertained high level of awareness followed by partial awareness (34.16\%) and least awareness (18.33\%).

\section{v. Awareness regarding method of sowing:}

Regarding awareness of method of sowing (By Seed-Drill $\&$ acc. to the availability of machinery) showed, out of the total beneficiaries, majority of the beneficiaries $(49.16 \%)$ pertained high level of awareness followed by partial awareness (38.33\%) and least awareness (12.50\%).

\section{vi. Awareness regarding cropping pattern:}

Regarding awareness of cropping pattern showed, out of the total beneficiaries, majority of the beneficiaries $(48.33 \%)$ pertained high level of awareness followed by partial awareness (26.66\%) and least awareness (25.00\%). vii. Awareness regarding cropping diversification:

Regarding awareness of cropping diversification showed, out of the total beneficiaries, majority of the beneficiaries $(43.33 \%)$ pertained partial level of awareness followed by high awareness (33.34\%) and least awareness (23.33\%).

\section{viii. Awareness regarding type offertilizer:}

Regarding awareness of type of fertilizer (FYM, Organic and Inorganic) showed, out of the total beneficiaries, majority of the beneficiaries $(37.50 \%)$ pertained high level of awareness followed by partial awareness $(37.49 \%)$ and least awareness $(25.01 \%)$.

\section{ix. Awareness regarding Fertilizer dose application:}

Regarding awareness of Fertilizer dose application $(N: P: K ; 20: 40: 20)$ showed, out of the total beneficiaries, majority of the beneficiaries $(35.83 \%)$ pertained partial level of awareness followed by high awareness $(35.00 \%)$ and least awareness (29.16\%).

x. Awareness regarding integrated weed
management:

Regarding awareness of integrated weed management showed, out of the total beneficiaries, majority of the beneficiaries $(46.67 \%)$ pertained high level of awareness followed by partial awareness $(30.00 \%)$ and least awareness (23.33\%).

xi. Awareness regarding integrated pest management: Regarding awareness of integrated pest management showed, out of the total beneficiaries, majority of the beneficiaries $(38.33 \%)$ pertained high level of awareness followed by partial awareness $(35.00 \%)$ and least awareness $(26.66 \%)$.

\section{xii. Awareness regarding level of production:}

Regarding awareness of level of production showed, out of the total beneficiaries, majority of the beneficiaries $(41.66 \%)$ pertained high level of awareness followed by partial awareness $(33.34 \%)$ and least awareness $(25.00 \%)$ respectively.

Regarding awareness of field preparation showed, out of the total beneficiaries, majority of the beneficiaries pertained high level of awareness followed by partial awareness and least awareness respectively. This result revealed that soybean growers have more awareness of field preparation because they are fully determined towards gaining the high production.

Regarding awareness of improved varieties of Soybean JS-9305 and JS-355 showed, out of the total beneficiaries, majority of the beneficiaries pertained high level of awareness followed by partial awareness and least awareness respectively. The result revealed that the improved varieties of soybean give yield than the local variety of soybean.

Regarding awareness of seed treatment (Carbendazim+Captan@3g m/ kg seed) showed, out of the total beneficiaries, majority of the beneficiaries pertained high level of awareness followed by partial awareness and least awareness respectively. This increases the diseases resistance of seeds which leads into higher production.

With respect to awareness of soil type showed, out of the total beneficiaries, majority of the beneficiaries pertained high level of awareness followed by partial awareness and least awareness respectively. The main reason behind the result is applicability of soil health card and high numbers of literate beneficiaries .

Regarding awareness of method of sowing (By Seed-Drill $\&$ acc. to the availability of machinery) showed, out of the total beneficiaries, majority of the beneficiaries pertained high level of awareness followed by partial awareness and least awareness respectively. 
Regarding awareness of cropping pattern showed, out of the total beneficiaries, majority of the beneficiaries pertained high level of awareness followed by partial awareness and least awareness respectively.

Regarding awareness of cropping diversification showed, out of the total beneficiaries, majority of the beneficiaries pertained partial level of awareness followed by high awareness and least awareness respectively.

Regarding awareness of type of fertilizer (FYM, Organic and Inorganic) showed, out of the total beneficiaries, majority of the beneficiaries pertained high level of awareness followed by partial awareness and least awareness res pectively.

Regarding awareness of Fertilizer dose application ( $N: P: K ; 20: 40: 20)$ showed, out of the total beneficiaries, majority of the beneficiaries pertained partial level of awareness followed by high awareness and least awareness respectively.

Regarding awareness of integrated weed management showed, out of the total beneficiaries, majority of the beneficiaries pertained high level of awareness followed by partial awareness and least awareness respectively.

Regarding awareness of integrated pest management showed, out of the total beneficiaries, majority of the beneficiaries pertained high level of awareness followed by partial awareness and least awareness respectively.

Regarding awareness of level of production showed, out of the total beneficiaries, majority of the beneficiaries pertained high level of awareness followed by partial awareness and least awareness respectively.

\section{REFERENCES}

[1] Arya,R.L., Arya,Sonam, Kurel,R.S. (2012) Indira Agriculture Competition Explorer, P.N.365.

[2] Awasthi, H. K.; Singh, P. R. and Sharma, R. N. (2000). Knowledge and attitude of dairy farmers towards improved dairy practices, Maharashtra J.Extn. Edn.,19:290-293.

[3] Darandale, A.D. (2010). A study on attitude of tribal farmers towards organic farming practices in maize crop. Unpublished M. Sc. (Agri.) Thesis, AAU, Anand.

[4] Gulkari (2011) Attitude of beneficiaries towards National Horticulture Mission Unpublished M. Sc. (Agri.) Thesis, AAU, Anand.

[5] Patel (2011) An Impact Analysis of Peasantry Modernization in Agriculture under Integrated Tribal Development Project of Vadodara District. Ph.D. (Agri.) Thesis, AAU, Anand.

[6] Satyaprakash, Kumari, N., Kumar, A. and De, D. (2010). To study the attitude of beneficiaries towards the technology dissemination programme of ATMA. J. C. S., 18: 206-209. 